PRODUCTION

ENGINEERING ARCHIVES
2016, Vol. 11, No 2, pp 2-5

ISSN 2353-5156

ISSN 2353-7779 (print version)

(online version)

Article history: Received: 16.05.2016 Accepted: 15.06.2016 Online: 30.06 .2016

\title{
Processing and utilization of metallurgical slag
}

\author{
Alena Pribulová ${ }^{1}$, Peter Futáš ${ }^{1}$, Dana Baricová ${ }^{1}$ \\ ${ }^{1}$ Institute of Metallurgy, Faculty of Metallurgy, Technical university in Košice, Park Komenského 14, Košice, Slovakia, +421556022752 , \\ e-mail: alena.pribulova@tuke.sk
}

\begin{abstract}
Metallurgy and foundry industry create a huge amount of slags that are by-products in production of pig iron, steel and cast iron. Slag is produced in a very large amount in pyrometallurgical processes, and is a huge source-of waste if not properly recycled and utilized. With rapid growth of industrialization, land available for land-filling of large quantity of metallurgical slag is being reduced all over the world and disposal cost is becoming increasingly higher. Metallurgical slag from different metallurgical processes treated and utilized in different ways based on different slag characteristics. The most economic and efficient option for reducing metallurgical waste is through recycling, which is a significant contribution to saving natural resources and reducing $\mathrm{CO}_{2}$ emissions. Characteristic of slags as well as its treatment and utilization are given in the paper. Slag from pig iron and steel production is used most frequently in building industry. From experiments using blast furnace slag and granulated blast furnace slag as gravel, and water glass as binder it can be concluded that that the best results - the best values of compression strength and tensile strength were reached by using of $18 \%$ of water glass as a solidification activating agent. According to cubic compression strength, mixture from 50\% blast furnace gravel, 50\% granulated blast furnace slag and $18 \%$ water glass falls into C35/45 class of concrete. Such concrete also fulfils strength requirements for road concrete, moreover, it even exceeds them considerably and, therefore, it can find an application in construction of road communications or in production of concrete slabs.
\end{abstract}

Key words - metallurgical slag, waste, concrete, cement

\section{Introduction}

Metallurgical slag has been used for decades with good results and it has its own loyal users. The EU Directive on Waste (75/442/ETY) defines waste as follows: "Waste" shall mean any substance or object, which the holder discards or intends or is required to discard. In addition to the definition of waste, the European list of waste (2000/532/EC) can be used to define whether a material is waste or not.

(HAMI S. 2005).

Metallurgical slag from different metallurgical processes is treated and utilized in different ways based on different slag characteristics. The most eco- nomic and efficient option for reducing the metallurgical waste generation is through recycling.

It is possible to divide metallurgical slag from ferrous metallurgy into six types: blast furnace slag (BFS), basic oxygen furnace slag (BOFS), electric arc furnace slag (EAFS), electric induction furnace slag (EIFS), cupola furnace slag (CFS) and slag from secondary metallurgy (PriBuloví A. 2014).

Blast furnace slag forms about $20-35 \%$ of the amount of hot metal produced. Molten slag tapped from the blast furnace is quenched mainly by using two alternative methods (REUTER M. 2004):

- Rapid water quenching, which does not give slag time to crystallise, but it vitrifies. Granulated blast 
furnace slag can also be used in earth and road construction.

- Slow air quenching, in which slag crystallises and solidifies into thick layers. Air quenched slag is crushed and screened to products required by customers. Air quenched blast furnace slag products are mainly used for earth and road construction.

As compared to blast furnace slag, steelmaking slag shows a considerably higher content of iron, manganese, and magnesium (GANDHEVAR V.R. 2011 REX M. 2013) along with the lower silicon content i.e. higher $\mathrm{CaO} / \mathrm{SiO} 2$ ratio, and, finally, it contains almost no sulphur at all. Slag from EAF has more weight, higher hardness and density, it is less porous and highly resistant to polishing and wear and as such is suitable for road building (LEWIS D.W. 1982, MOTZ H. 2001).

Electric arc furnace (EAF) slag can be used as an inexpensive absorbing agent (RASTOVČAN-MIOČ A. 2006).

The largest amount of steel slag is used in construction industry. However, its usage in case of more demanding applications is only possible after free lime stabilization. In such a case slag can be used as support slag gravel in road-building or a fine gravel aggregate in asphalt surface (MERKE T. 2007). This material is suitable for use as protection of river banks from erosion, as stabilization of profiles of water courses, or as a material for bank dike construction (KUJALA K. 2005).Very interesting usage options are desribed in literature references (TAKAHASHI T. 2002) where steel slag was utilized in production of the so-called sea blocks used in artificial cliff building.

\section{Utilization of blast furnace slag for concrete production}

Concrete is a composite material composed mainly of water, aggregate, and cement. Additives and reinforcements are usually included to achieve the desired physical properties of the finished material. When these ingredients are mixed together, they form a fluid mass that is easily molded into shape. Over time, the cement forms a hard matrix which binds the rest of the ingredients together into a durable stone - like material with many uses.
"Aggregate" consists of large chunks of material in a concrete mix, generally coarse gravel or crushed rocks such as limestone, or granite, along with finer materials such as sand. Concrete can be formulated with high compressive strength, but it always has lower tensile strength. For this reason, it is usually reinforced with materials that are strong. Fine and coarse aggregates make up the bulk of a concrete mixture. Sand, natural gravel, and crushed stone are used mainly for this purpose. Recycled aggregates (from construction, demolition, and excavation waste) are increasingly used as partial replacements of natural aggregates, while a number of manufactured aggregates, including air-cooled blast furnace slag and bottom ash are also permitted (BÖMER S., et all. 2007, YILDIRIM I.Z., PREZZI M. 2011).

\section{Methodology of research}

At the Institute of Metallurgy the blast furnace slag gravel was used for concrete production with cement and within it.

The blast furnace slag was used as a grave for cementless concrete. The proportion of ground granulated slag, which substituted cement was established experimentally and amounted to 50\% of the mixture consisting of blast furnace gravel and ground granulated slag. By initial experiments $25 \%$ granulated slag was used which approximately corresponded to a proportion of cement in cement concrete mixtures, but prepared cementless mixtures had low value of strength, the amount of granulated blast furnace slag was double.

Determination of proportion of particular fractions of blast furnace gravel was based on Fullers' curve. Fraction of $0-4 \mathrm{~mm}(43 \%)$ and $4-8 \mathrm{~mm}(7 \%)$ were used (BARICOVÁ D.,Pribulová A.,DEMETER P., BulKo B., Rosová A.2012, BARICOVÁ D., Pribulová A., Demeter P., BulKo B., Futáš P. 2011). Subsequently, water-glass as an activating agent of solidification was added into homogenized mixture and the whole mixture was stirred for two minutes. Cubic and cross - beam moulds were filled with the mixture, which was subsequently rammed by pneumatic ramming machine and then set for 24 hours. Afterwards, the samples were unmoulded and sub- 
merged into water environment (D sample was also set on the air) for 7 and 28 days.

Water glass, as the activating agent of solidification, was chosen based on acceptable price, good manipulability, as well as air-setting option. Three various types of water glass were examined for cementless concrete production: $36-38^{\circ} \mathrm{Bi}, 44-46^{\circ}$ Bé, $50-52^{\circ}$ Bé. The best compression and tensile strength were achieved by mixtures with water glass $50-52^{\circ}$ Bé, which became the basis for the next experiments.

Six mixtures with $50 \%$ blast furnace slag (43\% fraction $0-4 \mathrm{~mm}$ and $7 \%$ fraction $4-8 \mathrm{~mm}$ ), $50 \%$ granulated blast furnace slag and different addition of water glass $(6,12,16,18,20$ and $22 \%)$ were made.

Table 1 shows the addition of water glass in single mixtures and reached the values of compression and tensile strength. Mixture "A" and "B" with 6 and 12\% of water glass were disintegrated after 12 hours.

Table 1. Content of water glass in mixtures and reached values of compression and tensile strength

\begin{tabular}{|c|c|c|c|}
\hline Mixture & $\begin{array}{c}\text { Water glass } \\
50-52^{\circ} \text { Bé } \\
{[\mathrm{MPa}]}\end{array}$ & $\begin{array}{c}\text { Compression } \\
\text { strength } \\
{[\mathrm{MPa}]}\end{array}$ & $\begin{array}{c}\text { Tensile } \\
\text { strength } \\
{[\mathrm{MPa}]}\end{array}$ \\
\hline A & 6 & - & - \\
\hline B & 12 & - & - \\
\hline C & 16 & 34.5 & 2.9 \\
\hline D & 18 & 42 & 5.8 \\
\hline E & 20 & 41 & 5 \\
\hline F & 22 & 42 & 4.4 \\
\hline
\end{tabular}

Source: own study

\section{Results and discussions}

The best mechanical properties were reached by mixture D with $18 \%$ water glass, compression strength was $42 \mathrm{MPa}$ and tensile strength 5,8 $\mathrm{MPa}$. It is generally known that strength properties change over time, the strength increases slightly and then remains stable. Table 2 shows that compression strength after 7 days was $41,5 \mathrm{MPa}$ but after the next 21 days it increased to $49 \mathrm{MPa}$. The situation with tensile strength was similar.
Table 2. Compression and tensile strength of mixture $D$ (50\%blast furnace slag-50\% granulated slag $+18 \%$ water glass) after 7 and 28 days

\begin{tabular}{|c|c|c|c|}
\hline \multicolumn{2}{|c|}{ Compression strength $[\mathrm{MPa}]$} & \multicolumn{2}{|c|}{ Tensile strength $[\mathrm{MPa}]$} \\
\hline 7 days & 28 days & 7 days & 28 days \\
\hline 41.5 & 49 & 4.3 & 5.1 \\
\hline
\end{tabular}

Source: own study

As an alternative to water environment, in which all prepared mixtures were temporarily set, the environment of air atmosphere was chosen for the process of hardening. It was due to concerns that water environment may reduce hardening effects of water glass, as water reduces its density, Table 3 . It results from the values of compression and tensile strength that the difference of compression strength is minimal and even in favour of water environment, which is more distinctive at tensile strength. It is possible to state that water environment does not reduce hardening effects of water glass.

Table 3. Compression and tensile strength of mixture $D$ (50\%blast furnace slag-50\% granulated slag $+18 \%$ water glass) by different conditions of solidification

\begin{tabular}{|c|c|c|}
\hline $\begin{array}{c}\text { Condition of } \\
\text { solidification }\end{array}$ & $\begin{array}{c}\text { Compression } \\
\text { strength [MPa] }\end{array}$ & $\begin{array}{c}\text { Tensile strength } \\
{[\mathrm{MPa}]}\end{array}$ \\
\hline $\mathrm{D}_{\text {air }}$ & 41.5 & 4.3 \\
\hline $\mathrm{D}_{\mathrm{H} 2 \mathrm{O}}$ & 42 & 5.8 \\
\hline
\end{tabular}

Source: own study

\section{Summary and conclusions}

Metallurgy and foundry industry create a huge amount of slag that is a by-product in the production of pig iron, steel and cast iron. It is treated and utilized in different ways based on different slag characteristics. The most economic and efficient option for reducing metallurgical waste generation is through recycling.

Slag from pig iron and steel production is used most frequently in building industry.

The highest quantity of slag from foundry industry create in cupola furnace. Properties of cupola furnace slag are very similar to blast furnace slag but its utilization is minimal. From experiments using blast furnace slag and granulated blast furnace slag as gravel and water glass as a binder it can be concluded that the 
best results - the best values of compression strength and tensile strength were reached by using of $18 \%$ of water glass as solidification activating agent.

According to cubic compression strength, mixture D falls into C35/45 class of concretes. This concrete also fulfils strength requirements for road concrete, it even exceeds them considerably and, therefore, it could find an application in construction of road communications or in production of concrete slabs. It is necessary to examine the properties of given concrete during long-term field application. Production of such concrete mixtures would ensure efficient utilization of secondary raw materials developed from blast-furnace slag.

\section{Acknowledgement}

This work was supported by the Scientific Grant Agency of the Ministry of Education of the Slovak Republic No.VEGA 1/0703/16

\section{Literature}

1. Baricová D., Pribulová A., Demeter P., BULKO B., FUTÁŠ P. 2011. Analysis of metallurgical slags utilization in the road engineering. SGEM 2011 11th International Multidisciplinary Scientific GeoConference. Bulgaria. Albena.

2. Baricová D., Pribulová A., Demeter P., BulKo B., Rosová A. 2012. Utilizing of the metallurgical slag for production of cementless concrete mixtures. Metalurgija. Vol. 51. No. 4.

3. BÖMER S., et all. 2007. Aggregate case study. Final Report referring to contract $\mathrm{n}^{\circ} 150787-2007$ F1SC-AT. Vienna.

4. GandheVar V.R., Bansod S.V., Borade A.B. 2011. Induction furnace - a review. International Journal of Engineering and Technology Vol.3.No.4.

5. HAMI S. 2005. Slag: product or waste - the present situation. EUROSLAG. Slags - Providing Solutions for Global Construction and other Markets, 4th European Slag Conference. Proceeding, Euroslag Publicatio. Oulu (Finland).

6. KuJALA K. 2005. Use of industrial co-products in civil engineering in Slag-Providing solutions for global construction and other markets. 4th European Slag Conference. Oulu (Finland).

7. LEWIS D.W. 1982. Properties and Uses of Iron and Steel Slags. National Slag Association. Symposium on Slag National Institut for Transport and Road Research, South Africa.

8. MERKE T. 2007. Steel Slag for Railway Tracks. 5th European Slag Conference. Luxemboug.

9. Motz J., Geisler J. 2001. Products of Steel Slag an Opportunity to Save Natural Resources. Waste Management 21.

10. PRibulová A., FutÁŠ P., BARICOVÁ D., DEMETER,P. 2014. Waste management metallurgical slag: waste or secondary material? Toyotarity. Management of technology. Alba Iulia.

11. RastovČan - MioČ A., Sofilič T., MioČ B. 2006. Study of Potential Electric Arc Furnace Slag Application. Proceedings Book of 7th International Foundrymen Conference. Opatija.

12. Reuter M., XiaO Y., Boin U. 2004. Recycling and environmental issues of metallurgical slags and salt fluxes. VII International Conference on Molten Slags Fluxes and Salts, The South African Institute of Mining and Metallurgy. Johannesburg.

13. REX M. 2013. The use of BF, converter and ladle slags in European agriculture-benefits or risks? Slag-Providing solutions for global construction and other markets. In: 4th European Slag Conference. Oulu (Finland).

14. TAKAhashi T., YABUTA K. 2002. Applications for Iron and Steelmaking Slag. NKK Technical Review. No. 87.

15. YILDIRIM I.Z., PREZZI M. 2011. Chemical, Mineralogical, and Morphological Properties of Steel Slag. Advances in Civil Engineering. Vol. 10. 